\title{
Effect of seed coat rupture on the germination of Mimosa flocculosa Burkart (Leguminosae) seeds ${ }^{1}$
}

\author{
(D) Maiara Iadwizak Ribeiro ${ }^{2,5}$, (D) Guilherme Almeida Garcia Rodrigues ${ }^{3}$, (D) Gabriele Larissa Mathias ${ }^{4}$, \\ (D) Shirley Martins Silva ${ }^{4}$, iD Jaqueline Malagutti Corsato e e (D) Andréa Maria Teixeira Fortes ${ }^{4}$
}

Received: 23.01.2020; accepted: 17.06.2020

How to cite: Ribeiro, M.I., Rodrigues, G.A.G., Mathias, G.L., Silva, S.M., Corsato, J.M. \& Fortes, A.M.T. 2020. Effect of seed coat rupture on the germination of Mimosa flocculosa Burkart (Leguminosae) seeds. Hoehnea 47: e072020. http://dx.doi.org/10.1590/2236-8906-07/2020

\begin{abstract}
Effect of seed coat rupture on the germination of Mimosa flocculosa Burkart (Leguminosae) seeds). Mimosa flocculosa Burkart is a native species used for the recovery of degraded areas. Large scale seedling production in nurseries is hindered due to seed physical dormancy. This study evaluated the germination and seed coat anatomy of $M$. flocculosa seeds subjected to dormancy overcome treatments. Seeds of $M$. flocculosa were subjected to: control with distilled water, heated water at 50,80 and $100{ }^{\circ} \mathrm{C}$, and $\mathrm{H}_{2} \mathrm{SO}_{4}$ for 1,3 and 5 minutes. Germination tests were conducted with four replicates of 25 seeds in an entirely casualized delineation, analyzing germination percentage, mean germination time and germination speed index. Moreover, anatomical analysis of the seed coat was conducted. The treatments with heated water at $80^{\circ} \mathrm{C}$, and sulfuric acid for 3 and 5 minutes promoted benefic anatomical alterations in the seed integument, reflecting in higher and faster in germination rates. Heated water at $80^{\circ} \mathrm{C}$ is recommended because of its efficiency and safety.

Keywords: heated water, native species, physical dormancy, reforestation, sulfuric acid
\end{abstract}

RESUMO - (Efeito da ruptura do tegumento na germinação de sementes de Mimosa flocculosa Burkart (Leguminosae)). Mimosa flocculosa Burkart é uma espécie nativa, utilizada para recuperação de áreas degradadas. Porém, a produção de mudas em larga escala é dificultada pela dormência tegumentar presente na semente. Esse trabalho avaliou a germinação e a anatomia do tegumento de sementes submetidas à tratamentos de superação da dormência. Sementes de $M$. flocculosa

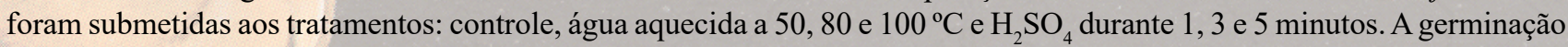
contou com quatro repetições de 25 sementes em delineamento inteiramente casualizado. As variáveis analisadas foram: germinação, tempo médio e índice de velocidade de germinação. Foram realizadas ainda análises anatômicas do tegumento das sementes. Os tratamentos usando água a $80^{\circ} \mathrm{C}$, e ácido sulfúrico por 3 e 5 minutos promoveram mudanças anatômicas benéficas no tegumento da semente, refletindo no aumento da porcentagem e velocidade de germinação. Recomendamos a água aquecida a $80^{\circ} \mathrm{C}$ pela eficiência e maior segurança na manipulação.

Palavras-chaves: ácido sulfúrico, água aquecida, dormência física, espécie nativa, recuperação de áreas

\section{Introduction}

Native Brazilian forests constantly undergoes deforestation caused by socioeconomic growth. In 1890 , forests covered $85 \%$ of the whole territory of Paraná State, while a hundred years later, this size decreased to only $3.5 \%$ (Meneghello \& Mattei 2004, Rodrigues 2015).

From that perspective, there has been an increase in studies aiming to identify efficient methods to promote the recovery of degraded areas. Planting of seedlings

1. O trabalho faz parte da Dissertação de Mestrado da primeiro Autora

2. Instituto de Botânica, Avenida Miguel Stéfano, 3687, Água Funda, 04301-902 São Paulo, SP, Brasil

3. Universidade Federal de Santa Catarina, Rua Engenheiro Agrônomo Andrei Cristian Ferreira, s/n, Trindade, 88040-900 Florianópolis, SC, Brasil

4. Universidade Estadual do Oeste do Paraná, Rua Universitária, 1619, Universitário, 85819-170 Cascavel, PR, Brasil

5. Autor para correspondência: maiara.iadwizak@gmail.com 
and direct seed sowing using seeds of native species of different successional stages are among the most common methods, aiming to promote natural ecological succession and reestablishment of the local biodiversity (Fonseca et al. 2001, José et al. 2005, Pereira \& Rodrigues 2012). In order to apply these methods efficiently, native seeds with high vigor are needed (Kageyama et al. 2003). However, more than half of the native species present seed dormancy (Baskin \& Baskin 2005, Souza et al. 2015).

Seed dormancy is caused by factors within the seed, preventing seeds from germinating even during suitable ecological conditions. Physical dormancy is the most reported type of dormancy for native species and is also known as integumentary dormancy, which is presented as a physical barrier that controls gas changes and water uptake in the seeds (Alexandre et al. 2009, Marcos-Filho 2015). This type of dormancy is considered common among Leguminosae species, at which the physical barrier is presented as a layer of palisade thick-walled cells called macrosclereids (Baskin \& Baskin 2000, Souza et al. 2015, Marcos-Filho 2015).

Ecologically, dormancy is a beneficial evolutionary adaptation because it delays germination, allowing seed dispersal throughout space and time. On the other hand, since it impedes efficient nursery seedling production, methods to overcome dormancy are essential. Several methods can be used, but the efficiency of each varies among species (Baskin \& Baskin 2001, Baskin \& Baskin 2005).

Mimosa flocculosa Burkart (Leguminosae), popularly known as Bracatinga de Campo-Mourão, is a native species indicated and highly used in degraded area recovery that presents physical dormancy and occurs in Mixed Ombrophilous and Stationary Semideciduous Forests (Carvalho 2002, Carvalho 2003).

Mimosa flocculosa is considered a pioneer species of small size and fast growth that is pollinized by bees and other insects, and therefore has potential for honey production (Carvalho 2002). The species has a short life cycle, which also promotes accumulation of litter and consequently benefits the ecological succession and arrival of new species in the area (Shibata et al. 2014, Shibata et al. 2016).

Several studies are conducted in order to find the method that better increases productivity and simultaneous germination for each species, and the most common treatments use either heated water, stratification, chemical or mechanical scarification (Vivian et al. 2008). Recent studies with M. flocculosa seeds were conducted by Shibata et al. 2014 and Shibata et al. 2016. In 2014, the authors compared two different lots and divided seeds in two categories, light and dark seeds, to verify if there was a difference in the dormancy overcome. The highest germination $(59 \%)$ was presented by the treatment with sulfuric acid for 1 minute in dark seeds. In 2016, Shibata et al. verified the most adequate substrate and temperature for germination of the species, which stand out sand at 20 and $30^{\circ} \mathrm{C}$.

In order to increase native seedling production in nurseries and consequently improve the recovery of degraded areas, this study verified the efficiency of treatments of physical dormancy overcome on the seed coat and germination of M. flocculosa seeds.

\section{Material and Methods}

The experiment was conducted between January and March 2018 in the Plant Physiology Laboratory of the Universidade Estadual do Oeste do Paraná, Cascavel, Paraná State, Brazil. The seeds of Mimosa flocculosa Burkart used in this study were collected in 2017. After pod collection and seed extraction, initial water content was evaluated and seeds were stored in a cold chamber at $4{ }^{\circ} \mathrm{C}$.

Dormancy overcome essay - Seeds were submersed in distilled water at several temperatures or concentrate sulfuric acid $98 \%$ for different periods of time as described on table 1 . After the application of the following treatments, seeds were rinsed in running water for 3 minutes to wash out any remnant of the solutions.

Germination essay - After the application of the treatments described on table 1, M. flocculosa seeds were placed in "Germitest" roll papers moistened with 2.5 times of the paper weight with distilled water and stored in a germination chamber (TE-4020 TECNAL) at $25^{\circ} \mathrm{C}$ and $12 \mathrm{~h}$ photoperiod (Brasil 2013). Each treatment consisted of four replicates of 25 seeds, organized in a completely randomized delineation. Although we evaluated seeds for 45 days, after 14 days of germination tests seeds were highly deteriorated by fungi and presented no differences in germination. Therefore, as other studies (Shibata et al. 2014, Shibata et al. 2016), we opted to present the results of the two-week evaluation period, as recommended by Brasil (2013). Seeds were considered germinated when they presented at least $2 \mathrm{~mm}$ of primary root protrusion (Hadas 1976). The parameters analyzed were germination percentage, mean germination time (MGT) (Edmond \& Drapala 1958) and germination speed index (GSI) (Silva \& Nakagawa 1995).

For statistical analysis, Shapiro-Wilk test for normality and the Levene's test for homogeneity of variances were performed, followed by the one-way ANOVA and Tukey tests. For each analysis a 5\% significance level was used. Software used was RStudio 3.2.2.

Seed Coat Anatomical analysis - The seeds subjected to different treatments (CW, W50, W80, W100, SA1, SA3 and SA5) were fixed with FAA 50 (Johansen 1940), preserved in ethanol 70\%, dehydrated in ethanolic series and included in Leica historesin (following fabricant orientations). Before fixation, in order to optimize the historesin infiltration, seeds were cut transversely in the median hilum-region and longitudinally in the median raphe-region. We analyzed the integument structure opposed to where the infiltration cuts were made, by producing transversal and longitudinal sections of $5 \mu \mathrm{m}$ width using a rotary microtome (Leica RM 2245). Sections were stained with toluidine blue $0.05 \%$ (O'Brien et 
al. 1964) and Entellan was used to mount permanent slides. Section images were captured using a photomicroscope Olympus Bx70 by the program DP Controller. The terminology of the structure used were according to the revision proposal of Souza \& Marcos-Filho (2001).

\section{Results}

The treatments that promoted the highest germination rates and also higher GSI were W80 (84\%), SA5 (82\%) and SA3 (77\%). SA1 also increased the germination percentage $(50 \%)$, while $\mathrm{W} 100$ and $\mathrm{W} 50$ presented the same germination rates as the control (Table 2). Only $21 \%$ of the $\mathrm{CW}$ seeds germinated. Seeds took between 2 and 4 days to germinate and no difference was observed for MGT between the treatments.

The seed coat of M. flocculosa is constituted externally by one layer of elongated and juxtaposed cells (macrosclereids
(Mc) or palisade layer), with thick-walled and reduced lumen covered by cuticle $(\mathrm{Ct})$, as observed in the figure $1 \mathrm{a}$. The light line (Ll) is also observed in the distal region of palisade layer. Internally, there is a single layer of shorter cells and with a wider lumen than in the palisade layer, called the hourglass cells $(\mathrm{Hc})$. These cells also presented thick walls, but they are separated by intercellular spaces. The exotesta (Ex) region is composed by the palisade layer and the hourglass cells (figure $1 \mathrm{a}$ ). The hourglass layer is followed by several layers (4-8) of parenchymatic cells $(\mathrm{Pc})$ tangentially elongated, with thinwalled and dense protoplasm, known as mesotesta $(\mathrm{Me})$ region.

In the treatments for dormancy overcome using either heated water or with acid caused damage mainly in the palisade layer (figure $1 \mathrm{~b}$-d). In the W80, we observed fissures mainly in the anticlinal cell-walls of the macrosclereids (figure $1 \mathrm{~b}$ ). In contrast, in the SA3 (figure $1 \mathrm{c}$ ) and SA5 (figure $1 \mathrm{~d}$ ) we noticed corrosion of the superficial region of the palisade layer, with removal of the cuticle (figure $1 \mathrm{c}-\mathrm{d}$ ).

Table 1. Treatments applied for dormancy overcome. Lines indicate the abbreviations used for each treatment throughout the text and their corresponding solutions, temperatures and immersion times. CW: control with no immersion. W50: immersion in distilled water at $50^{\circ} \mathrm{C}$ for $10 \mathrm{~min}$. W80: immersion in distilled water at $80^{\circ} \mathrm{C}$ for $10 \mathrm{~min}$. W100: immersion in distilled water at $100^{\circ} \mathrm{C}$ for $10 \mathrm{~min}$. SA1: immersion in concentrated sulfuric acid for $1 \mathrm{~min}$. SA3: immersion in concentrated sulfuric acid for $3 \mathrm{~min}$. SA5: immersion in concentrated sulfuric acid for $5 \mathrm{~min}$.

\begin{tabular}{cccc}
\hline Treatment & Solution & Temperature & Time (minutes) \\
\hline CW (control) & Distilled water & Ambient & - \\
W50 & Distilled water & $50{ }^{\circ} \mathrm{C}$ & 10 \\
W80 & Distilled water & $80{ }^{\circ} \mathrm{C}$ & 10 \\
W100 & Distilled water & $100{ }^{\circ} \mathrm{C}$ & 10 \\
SA1 & Sulfuric acid & Ambient & 1 \\
SA3 & Sulfuric acid & Ambient & 3 \\
SA5 & Sulfuric acid & Ambient & 5 \\
\hline
\end{tabular}

Table 2. Germination (\%), mean germination time (MGT) (days) and germination speed index (GSI) of Mimosa flocculosa Burkart seeds subjected to different overcoming dormancy treatments. CW: control with no immersion. W50: immersion in distilled water at $50{ }^{\circ} \mathrm{C}$ for $10 \mathrm{~min}$. W80: immersion in distilled water at $80^{\circ} \mathrm{C}$ for $10 \mathrm{~min}$. W100: immersion in distilled water at $100^{\circ} \mathrm{C}$ for $10 \mathrm{~min}$. SA1: immersion in concentrated sulfuric acid for $1 \mathrm{~min}$. SA3: immersion in concentrated sulfuric acid for $3 \mathrm{~min}$. SA5: immersion in concentrated sulfuric acid for $5 \mathrm{~min}$.

\begin{tabular}{cccc}
\hline Treatment & Germination (\%) & MGT (days) & GSI \\
\hline CW & $21 \mathrm{c}$ & $4.05 \mathrm{a}$ & $6.98 \mathrm{~b}$ \\
W50 & $29 \mathrm{c}$ & $3.05 \mathrm{a}$ & $15.43 \mathrm{~b}$ \\
W80 & $84 \mathrm{a}$ & $2.91 \mathrm{a}$ & $46.91 \mathrm{a}$ \\
W100 & $38 \mathrm{bc}$ & $3.17 \mathrm{a}$ & $18.88 \mathrm{~b}$ \\
SA1 & $50 \mathrm{~b}$ & $3.20 \mathrm{a}$ & $22.95 \mathrm{~b}$ \\
SA3 & $77 \mathrm{a}$ & $2.78 \mathrm{a}$ & $46.28 \mathrm{a}$ \\
SA5 & $82 \mathrm{a}$ & $2.73 \mathrm{a}$ & $51.14 \mathrm{a}$ \\
Average & - & 3.12 & - \\
C.V. (\%) & 15.65 & 31.15 & 29.99 \\
\hline
\end{tabular}

Values followed by the same letter in the column do not differ by Tukey test at $5 \%$ probability. C.V.: coefficient of variation. 

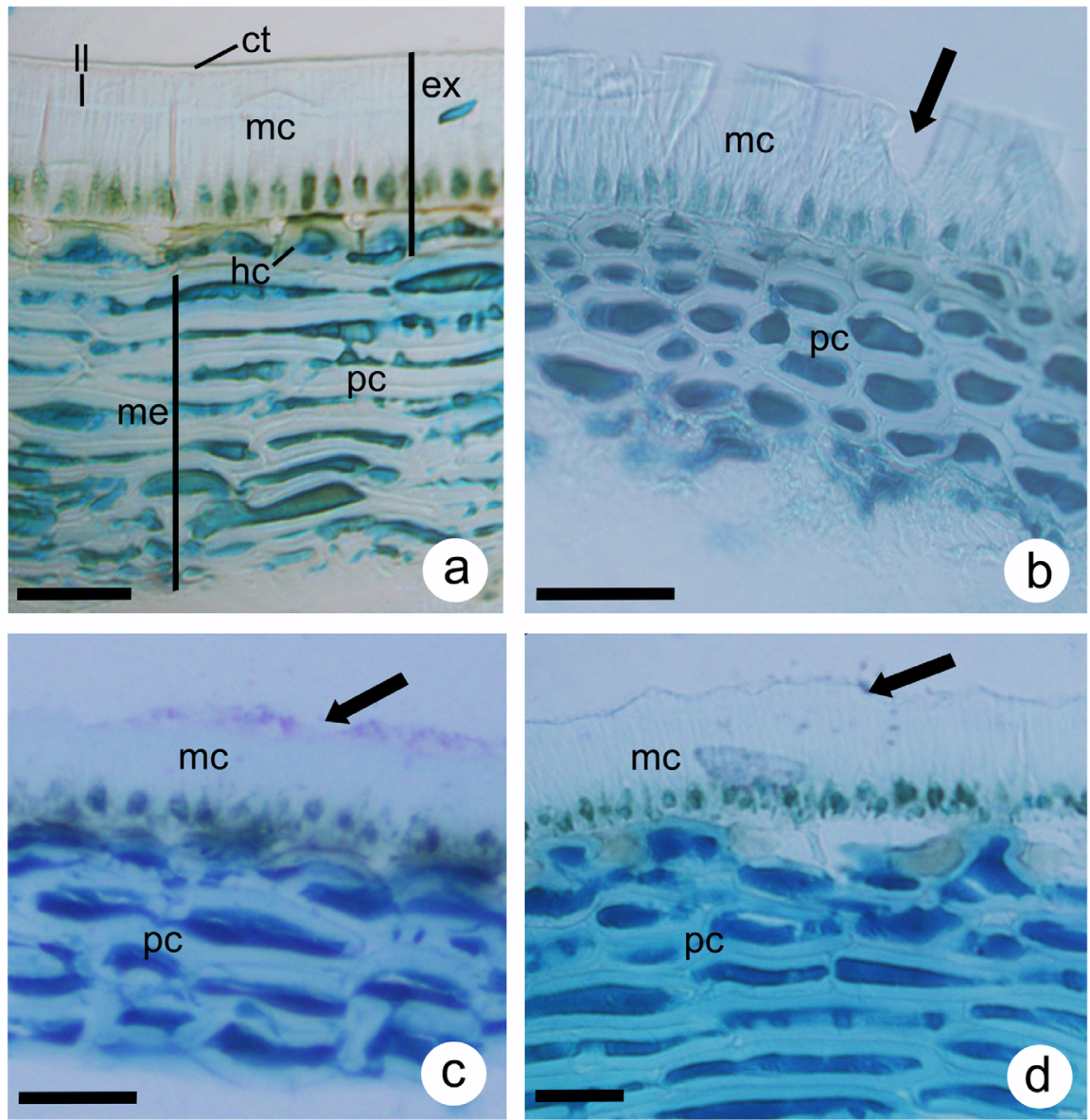

Figure 1. Transversal cuts from the seed coat of Mimosa flocculosa Burkart subjected to treatments for dormancy overcome. a. general structure of the integument of the control $(\mathrm{CW})$. b. fissures in the cell walls of the macrosclereids after the heated water treatment at $80{ }^{\circ} \mathrm{C}$ for $10 \mathrm{~min}$ (W80). c. corrosion of the macrosclereids cells (arrow) in the sulfuric acid treatment for 3 min (SA3). d. corrosion of the cuticle and macrosclereids (arrow) cells caused by the exposure to sulfuric acid for 5 min (SA5). mc: macrosclereids or palisade layer; ct: cuticle; ex: exotesta; hc: hourglass cells; ll: lucid line; me: mesotesta; pc: parenchyma cells.

\section{Discussion}

The structure of the seed coat observed in M. flocculosa $\mathrm{CW}$ seeds are similar to those described for other species from the same genus, as Mimosa daleoides Benth., M. dolens Vell. var. anisitsii (Lindm.) Barneby and M. orthacantha Benth, and also from other Leguminosae genera, specially the waxy cuticle that cover the macrosclereids (Iwasaki 2008, Molizane et al. 2018). These characteristics are responsible for the rigidity and impermeability of the integument, hampering gas changes and water uptake by the seed and consequently resulting in the physical dormancy (Perez 2004, Marcos-Filho 2015).

The occurrence of physical dormancy in M. flocculosa was confirmed by the efficacy of some treatments (W80, SA3 and SA5) to promote higher germination rates $(84,77$ and $82 \%$, respectively) than the control (21\%). The results are reinforced by the structural changes observed in the seeds exposed to the dormancy overcome treatments, largely related to the cuticle removal and the damage to macrosclereid cells, which caused ruptures in the impermeable palisade layer. These ruptures promoted water uptake, which promotes tissue rehydration, and oxygen entrance, which intensifies the metabolic activities and the degradation of reserves within the seed, essential processes for embryonic axis growth (Rodrigues et al. 2019).

Similar results were described by Sperandio et al. (2013) using seeds of Mimosa setosa Benth, at which by using sulfuric acid for 1 and $3 \mathrm{~min}$ or water at $70^{\circ} \mathrm{C}$ and $80^{\circ} \mathrm{C}$ during 1,3 and $5 \mathrm{~min}$ obtained higher germination rates for the species (> 90\%). When studying Mimosa caesalpiniifolia Benth seeds, Passos et al. (2007) observed increases in germination $(89.5 \%)$ by using sulfuric acid P.A. during 4 min, which was similar to results found in this study for M. flocculosa.

The other treatments to dormancy overcome presented in this study that presented lower increase in germination (SA1) or the same percentages as the control (W50 and W100) were also tested similarly by Shibata et al. (2014) for M. flocculosa seeds of different colors, and the immersion in water at $50^{\circ} \mathrm{C}$ and sulfuric acid for $1 \mathrm{~min}$, also presented low germination ( $22 \%$ and $7 \%$, respectively). The dormancy overcome study conducted by Alencar et al. (2009) for Stylosanthes SW, another Leguminosae genus, also showed 
relatively low germination (40\%) when seeds were exposed to water at $50{ }^{\circ} \mathrm{C}$ during 5,10 and 15 hours.

The low germination percentage presented by $M$. flocculosa seeds in W50 may be explained by the fact that this treatment was not able to loosen the integument cell layers, and hence not being enough to increase water intake and consequently increase seed germination rates. On the other hand, W100 increased germination when compared to control, although not as efficiently as the other treatments (W80, SA3 and SA5). This might be attributed to the high temperature, which we suggest that caused damage in vital structures and therefore the loss of important functions, as the stability and permeability of cell membranes and the activity of enzymes, irreversibly compromising germination. Same results were found by Ribeiro et al. (2016) in Peltophorum dubium dormant seeds, in which seeds were unable to germinate when seeds were soaked in water at $100^{\circ} \mathrm{C}$ for $10 \mathrm{~min}$.

We also observed an increase in GSI for the treatments with highest germination (W80, SA3 and SA5), proving that the physical dormancy was the obstacle for a high and fast germination. Several authors highlight the importance of analyzing GSI in dormancy overcome treatments, especially because high GSI represents seed vigor and a trend of accelerating the germinative process (Lima \& Meiado 2017).

Mimos a flocculosa seeds presented the same MGT in all treatments, taking 2 to 4 days to start germination. Monteiro $\&$ Castilho (2014) studied treatments for overcoming dormancy of Peltophorum dubium seeds, and also found no difference in MGT between the analyzed treatments.

In accordance with the results found in our study, Santos et al. (2014) observed that in seeds of Piptadenia viridiflora (Kunth) Benth the highest GSI values were found in dormancy overcome treatments using sulfuric acid. The acceleration of the germination process is considered beneficial, since the faster seeds germinate, the less they will be exposed to adverse conditions and pathogen incidence, which may lead to tissue deterioration. Moreover, faster germination tends to be more synchronized, a desirable characteristic in seedling production (Joshi \& Chinnusamy 2014, Rodrigues et al. 2019).

Similar to our results, Sperandio et al. (2013) obtained the greatest germination rates applying sulfuric acid and heated water in overcoming dormancy of Mimosa setosa Benth seeds, but stated the risk of handling sulfuric acid, since it is highly corrosive. Therefore, the authors suggested heated water as a better treatment, since it is cheaper and presents less risk for the nurseries. Moreover, after 14 days of evaluation, the only seeds that were not deteriorated by fungi were the $\mathrm{CW}$ seeds. To verify if the viability of these seeds was intact, we subjected the $\mathrm{CW}$ seeds to the best overcome dormancy treatment, i.e. distilled water at $80^{\circ} \mathrm{C}$ for $10 \mathrm{~min}$. All seeds germinated, confirming the efficacy of the W80 treatment and also the importance of the seed coat for seed integrity and vigor.

Finally, our study corroborates with several authors, confirming that applying sulfuric acid for 3 and 5 minutes is efficient to overcome the physical dormancy of Mimosa flocculosa seeds. On the other hand, water heated at $80^{\circ} \mathrm{C}$ has the same efficiency and is less expensive and safer to use, which are beneficial characteristics for seedling production in nurseries.

\section{Conclusion}

Among all treatments tested, the best for overcoming Mimosa flocculosa seed dormancy is heated water at $80^{\circ} \mathrm{C}$ and sulfuric acid for 3 and 5 minutes, since they promoted beneficial morphoanatomical changes in the integument that reflected in faster and higher germination rates.

\section{Aknowledgements}

We thank CAPES, for the financial support and Instituto Ambiental do Paraná, for seed collection and donation.

\section{Literature cited}

Alencar, K.M.C., Laura V.A., Rodrigues A.P.D.C. \& Resende R.M.S. 2009. Tratamento térmico para superação da dormência em sementes de Stylosanthes SW. (Fabaceae Papilionoideae). Revista Brasileira de Sementes 31: 164-170.

Alexandre, R.S., Gonçalves, F.G., Rocha, A.P., Arruda, M.P. \& Lemes, E.Q. 2009.Tratamentos físicos e químicos na superação de dormência em sementes de Enterolobium contortisiliquum (Vell.) Morong. Revista Brasileira de Ciências Agrárias 4: 156-159.

Baskin, J.M. \& Baskin, C.C. 2000. Evolutionary consideration of claims of physical dormancy-break by microbial action and abrasion by soil particles. Seed Science Research 10: 409-413.

Baskin, C.C. \& Baskin, J.M. 2001. Seeds: ecology, biogeography and Evolution of dormancy and germination. Academic Press, Londres.

Baskin, C.C. \& Baskin, J.M. 2005. Seed dormancy in trees of clímax tropical vegetation types. Tropical Ecology 46: 17-28.

Brasil. 2013. Ministério da Agricultura, Pecuária e Abastecimento. Instruções para Análise de Sementes de Espécies Florestais. Brasília.

Carvalho, P.E.R. 2002. Bracatinga de Campo Mourão Colombo: Embrapa, 61:1-5.

Carvalho, P.E.R. 2003. Espécies arbóreas brasileiras. Brasília: Embrapa Informação Tecnológica; Colombo: Embrapa Floresta.

Edmond, J.B. \& Drapala, W.J. 1958. The effects of temperature, sand and soil, and acetone on germination of okra seed. Proceedings of the American Society Horticutural Science, 71: 428-434.

Fonseca, C.E.L., Ribeiro, J.F. \& Souza-Silva, J.C. 2001. Recuperação da vegetação de Matas de Galeria: estudos de caso no Distrito Federal e entorno. Cerrado - caracterização e recuperação de matas de galeria. Planaltina 1:815-867. 
Hadas, A. 1976. Water uptake and germination of leguminous seeds under changing external water potential in osmotic solution. Experimental of Botany 27:480-489.

Iwasaki, M.C. 2008. Frutos, sementes e plântulas de três espécies de Mimosa linnaeus (Fabaceae: Mimosoideae): aspectos morfoanatômicos e considerações ecológicofilogenéticas. Botucatu. Tese de Doutorado, Universidade Estadual Paulista, Botucatu.

Johansen, D.A. 1940. Plant microtechnique. McGraw- Hill Book, New York.

José, A.C., Davide, A.C. \& Oliveira, S.L. 2005. Produção de mudas de aroeira (Schunus terebenthifolius Raddi) para recuperação de áreas degradadas pela mineração de bauxita. Cerne, Lavras 11:187-196.

Joshi, R. \& Chinnusamy, V. 2014. Antioxidant enzymes: Defense against high temperature stress. In: Ahmad P. Oxidative Damage to Plants: Antioxidant Networks and Signaling.Elsevier Academic Press: 369-374.

Kageyama, P.Y., Sebbenn, A.M., Ribas, L.A., Gandara, F.B., Castellen, M., Perecin M.B. \& Vencovsky R. 2003. Diversidade genética em espécies arbóreas tropicais de diferentes estágios sucessionais por marcadores genéticos. Scientia Forestalis, 64:93-107.

Lima, A.T. \& Meiado, M.V. 2017. Escarificação Química como Método Eficiente para Superação da Dormência de Sementes de Lonchocarpus sericeus (Poir.) Kunth ex DC. (Fabaceae). Gaia Scientia, 11: 9-18.

Marcos-Filho, J. 2015. Fisiologia de sementes de plantas cultivadas. 2. ed., Londrina: ABRATES.

Meneghello, G.E. \& Mattei, V.L. 2004. Semeadura direta de timbaúva Enterolobium contortisiliquum, canafístula Peltophorum dubium e cedro Cedrela fissilis em campos abandonados. Ciência Florestal, 14: 21-27.

Molizane, D.M., Julio P.G.S., Carmello-Guerreiro, S.M. \& Barbedo, C.J. 2018. Physical, physiological and anatomical changes in Erythrina speciosa Andrews seeds from different seasons related to the dormancy degree. Journal of Seed Science 40: 331-341.

Monteiro, L.N.H. \& Castilho, R.M.M. 2014. Efeitos de diferentes tratamentos pré-germinativos em sementes de canafistula. Tecnologia e Ciência Agropecuária, 8: 57-60.

O'brien, T.P., Feder, N. \& Mccully, M.E. 1964. Polychromatic staning of plant cell walls by toluidine blue. Protoplasma 59: 368-373.

Passos, M.A., Tavares, K.M.P. \& Alves, A.R. 2007. Germinação de sementes de sabiá Mimosa caesalpiniifolia Benth. Revista Brasileira de Ciências Agrárias, 2: 51-56.

Pereira, J.S. \& Rodrigues, S.C. 2012. Crescimento de espécies arbóreas utilizadas na recuperação de área degradada. Caminhos de Geografia, 13:102-110.
Perez, S.C.J.G.A. 2004. Envoltórios. In: FERREIRA, A. G.; BORGHETTI, F. Germinação: do básico ao aplicado. Porto Alegre: Artmed, pp.125-134.

Ribeiro, M.I., Muller, E.V., Porto, E., Santos, J.A., Fortes, A.M.T., Martins, S. \& Corsato, J.M. 2016. Alterações no tegumento de sementes de Peltophorum dubium (Sprengel) Taubert submetidas a tratamentos de superação de dormência. Journal of Agronomic Sciences 5: 158-169.

Rodrigues, E.H.P. 2015. Espécies florestais para o uso econômico na reserva legal e propostas de modelos para implementação. Trabalho de conclusão de curso, Universidade Federal do Paraná Curitiba.

Rodrigues, G.A.G.; Ribeiro, M.I.; Luz, E.M.Z.; Porto, E.C.; Matias, G.L.; Corsato, J.M. \& Fortes, A.M.T. 2019. Drought stress effects on germination and reserve degradation of Aspidosperma polyneuron seeds. Revista Brasileira de Ciências Agrárias, 14(4): 1-10.

RStudio Team (2018). RStudio: Integrated Development for R. RStudio, Inc., Boston, MA. Disponível em http:// www.rstudio.com/.

Santos, L.J., Da-Luz, I.S., Matsumoto, S.M., D’arêde, L.O. \& Viana, A.E.L. 2014. Superação de dormência tegumentar de sementes de Piptadenia viridiflora (Kunth) Benth pela escarificação química. Biosciência Journal, 30:1642-1651.

Silva, J.B.C. \& Nakagawa, J. 1995. Estudos de fórmulas para cálculo de germinação. Informativo Abrates, 5: 62- 73.

Souza, F.H.D. \& Marcos-Filho, J. 2001. The seed coat as a modulator of seed-environment relationships in Fabaceae. Brazilian Journal of Botany, 24(4), 365-375.

Souza, T.V., Torres, I.C., Steiner N. \& Paulilo M.T.S. 2015. Seed dormancy in tree species of the Tropical Brazilian Atlantic Forest and its relationships with seed traits and environmental conditions. Brazilian Journal of Botany, 38: 243-264.

Sperandio, H.V., Lopes, J.C. \& Matheus, M.T. 2013. Superação de dormência em sementes de Mimosa setosa Benth. Comunicata Scientiae 4: 385-390.

Shibata, M., Oliveira, L.M. \& Pavelski, L.G. 2014. Avaliação da qualidade fisiológica de sementes de Mimosa flocculosa de diferentes colorações submetidas a tratamentos pré-germinativos. Revista de Ciências Agroveterinárias, 13: 40-46.

Shibata, M., Pavelski, L.G., Miranda, L. \& Oliveira, M.L. 2016. Germinação de sementes de Mimosa flocculosa. Magistra, 28: 131-136.

Vivian, R.S.A.A., Gimenes-Junior, M., Fagan, E.B., Ruiz, S.T. \& Labonia V. 2008. Dormência em sementes de plantas daninhas como mecanismo de sobrevivência breve revisão. Planta Daninha, 26: 695-706. 